\title{
CHEMICAL COMPOSITION OF ESSENTIAL OIL FROM Myrcia oblongata DC AND POTENCIAL ANTIMICROBIAL, ANTIOXIDANT AND ACARICIDAL ACTIVITY AGAINST Dermanyssus gallinae (DEGEER, 1778)
}

\author{
COMPOSIÇÃO QUÍMICA DO ÓLEO ESSENCIAL DE Myrcia oblongata DC E \\ POTENCIAL ANTIMICROBIANO, ANTIOXIDANTE E ACARICIDA CONTRA \\ Dermanyssus gallinae (DEGEER, 1778)
}

\author{
Camila Beatriz SANTANA ${ }^{1}$; Juliete Gomes de Lara SOUZA ${ }^{1}$; \\ Miryan Denise Araujo CORACINI ${ }^{1}$; Adriana Helena WALERIUS ${ }^{1}$; Vanessa Duarte SOARES ${ }^{2}$; \\ Willian Ferreira da COSTA ${ }^{2}$; Fabiana Gisele da Silva PINTO ${ }^{1}$ \\ 1. Program of Conservation and Management of Natural Resources, Biotechnology Laboratory, West of Paraná State University \\ (UNIOESTE), Cascavel - PR, Brazil; 2. Department of Chemistry, State University of Maringá (UEM), Maringá - PR, Brasil. \\ fabiana.pinto@unioeste.br
}

\begin{abstract}
Essential oils have aroused interest in the industrial sector due to the multitude of potential applications, especially with respect their antimicrobial and antioxidant properties, among others. The objective of this study was to determine the chemical composition of the essential oil from the leaves of Myrcia oblongata DC by gas chromatography coupled to mass spectrometry (GC-MS). To evaluate the antioxidant potential of the oil by using the free radical capture method with 2,2-diphenyl-1-picryl hydrazyl (DPPH); to test the oil antimicrobial activity using the broth microdilution method; and to evaluate the repellency and fumigant potential of the oil on Dermanyssus gallinae (Degeer, 1778). The GC-MS analysis resulted in the identification of 30 oil constituents, with the bulk of the composition identified as caryophyllene oxide $(22.03 \%)$ and trans-verbenol (11.94\%). The oil presented moderate antioxidant activity compared to the synthetic antioxidant 2,6-di-tert-butyl-4-hydroxytoluene (BHT). Antimicrobial activity of the essential oil showed an inhibitory activity on Gram-positive bacteria, Enterococcus faecalis, Staphylococcus aureus, Bacillus subtilis and Staphylococcus epidermidis and for the yeast Candida albicans, and showed no activity against Gram-negative bacteria. All concentrations of the essential oil used in the fumigation test on D. gallinae resulted in mortality below $20 \%$. For the repellency test, significant potential was observed for the concentration of $10 \%$.
\end{abstract}

KEYWORDS: GC-MS. Caryophyllene oxide. Dermanyssus gallinae

\section{INTRODUCTION}

The main products of plant origin used in the industrial sector are essential oils. These oils contain compounds of the secondary metabolism and are extracted from various parts of plants, and their chemical composition varies between different species and among anatomical structures (SARTORATTO et al., 2004; OUSSALAH et al., 2007). The essential oils stand out for their antimicrobial and antioxidant properties (MAHMOUDI et al., 2016) in addition to presenting potential pesticide activity against mites that are considered pests (BASER; BUCHBAUER, 2015).

The bioactivity of the essential oils can be exerted by different compounds, notably terpenoids (BURT, 2004) and including hemiterpenes, monoterpenes, or sesquiterpenes in addition to their derivatives (XAVIER et al., 2016). Among the families that concentrate these elements, Myrtaceae (CIPRIANI et al., 2012) has been recognized not only through investigations of the biological activity of the group but also due to the presence of essential oils (ACIOLE, 2001). This family has a natural distribution in all continents of the Southern Hemisphere, and is comprised of 145 genera and 5,970 species (THE PLANT LIST, 2013). In Brazil, the Myrtaceae occur mainly in the Atlantic forest and are represented by 1,025 species, belonging to 23 genera (SOBRAL et al., 2016).

Some Myrcia spp. (Myrtaceae) are used in folk medicine, especially Myrcia amazonica in which the leaves are used to treat leukemia (MORS et al., 2000), and Myrcia bracteata, used to treat rashes and cases of diarrhea (SIMÕES; SPITZER, 2004; Sá et al., 2012). However, there are few reports in the literature of the bioactivity and chemical composition of the essential oil of Myrcia oblongata DC. (CASCAES et al., 2015; SANTANA, 2017).

Despite the lack of reports on the bioavailability of $M$. oblongata, the essential oils of the family have recognized importance 
especially for their antimicrobial activity (SIMONETTI et al., 2016). Studies the antimicrobial properties of plant products have increased in the last decade due to the extensive and undue use of antimicrobials. There has been a significant increase in the frequency of resistant bacteria, which were previously known to be sensitive to routinely used drugs. Today, these bacteria are resistant to various drugs available in the market (KASPER; FAUCI, 2015), thus highlighting the importance of research on new compounds.

Another growing agricultural sector in Brazil is poultry farming, in which there are various problems associated with pests (PALERMO, 2015) such as Dermanyssus gallinae (Acari: Dermanyssidae), the chicken mite. This parasite can cause losses in poultry production due to its reproductive potential, and as a result producers utilize various types of synthetic products to combat the pest. This causes severe problems including pest resistance, high levels of residues, environmental and human intoxication, and destruction of natural enemies (SOTO et al., 2011). Due to this scenario, the use of plantbased repellents and acaricides deserves attention among alternative methods to conventional chemical pest control (SPARAGANO et al., 2014).

In order to develop new products with antimicrobial, acaricidal and other bioavailability potential, toxicity tests must be carried out to verify the safety of the essential oils; it is for this reason that evaluation of antioxidant activity is also of great importance (ROSA et al., 2016). In addition, the search for new antioxidant agents for use in industries has increased the resistance of pathogenic microorganisms to synthetic products (TEPE et al., 2004; XAVIER et al., 2016).

The objective of this study was to determine the chemical composition of the essential oil from the leaves of M. oblongata, to evaluate the antimicrobial and antioxidant activity of the essential oil and to verify its repellent and acaricidal activity against $D$. gallinae .

\section{MATERIAL AND METHODS}

\section{Collection, drying and identification of plant material}

Leaves of M. oblongata were collected from March to June 2016 in the autumn season at the Parque Ecológico Paulo Gorski $\left(24^{\circ} 56^{\prime} 14 "\right.$ to $24^{\circ} 58^{\prime} 17^{\prime \prime} \mathrm{S}, 53^{\circ} 25^{\prime} 14^{\prime \prime}$ to $53^{\circ} 27^{\prime} 06^{\prime \prime} \mathrm{W}$ ) in the municipality of Cascavel, Paraná, Brazil. Species identifications were carried out in the Herbarium of the Universidade Estadual do Oeste do Paraná (UNIOESTE), and the samples were registered under the number UNOP 1816.

The leaves were dried at $40{ }^{\circ} \mathrm{C}$ and milled in a Willy-type laboratory grinder to $0.42 \mathrm{~mm}$. The resulting powder was stored in glass containers protected from light at room temperature until extraction of the essential oil (CEYHAN et al., 2012; WEBER et al., 2014).

\section{Essential oil extraction}

Following the methodology proposed by Weber et al. (2014), $140 \mathrm{~g}$ of the dried M. oblongata plant material was added to $1.4 \mathrm{~L}$ of distilled water. The solution was placed in Clevenger apparatus following the hydrodistillation technique for approximately 3 hours. The extracted oil was stored in a freezer at $4{ }^{\circ} \mathrm{C}$ for later assays.

\section{Gas chromatography coupled to mass spectrometry (GC-MS)}

The identification of the compounds present in the essential oil was performed using a FOCUS GS (Thermo Electron) gas chromatograph coupled to a DSQ II mass spectrometer (Thermo Electron) and detector with $70 \mathrm{~V}$ electronic ionization impact and a quadrupole mass analyzer. For the chromatographic separation a capillary column of fused silicon DB-5 (internal diameter of $30 \mathrm{~m} \mathrm{x} 0.25$ $\mathrm{mm}$, film thickness $0.25 \mu \mathrm{m}$ ) and stationary phase of 5\% phenyl: 95\% dimethylpolysiloxane was used.

The initial temperature was $50{ }^{\circ} \mathrm{C}$ for $2 \mathrm{~min}$ with the injector temperature at $250{ }^{\circ} \mathrm{C}$, followed by an increase to $180^{\circ} \mathrm{C}$ at $2{ }^{\circ} \mathrm{C} \mathrm{min}^{-1}$ then $290{ }^{\circ} \mathrm{C}$ at 5 ${ }^{\circ} \mathrm{C} \min ^{-1}$. The interface between the GC and MS was maintained at $270{ }^{\circ} \mathrm{C}$, and the ionization source temperature for mass spectrometric analysis was $250{ }^{\circ} \mathrm{C}$. The support gas helium flow was kept constant at $1 \mathrm{~mL} \cdot \mathrm{min}^{-1}$. The sample and C7-C28 alkane standards were injected at a separation ratio of 1:25. The compounds were identified by comparison to the retention times in the literature (ADAMS, 2007) and through their retention indices.

\section{Antimicrobial activity}

The antimicrobial activity of essential oils was evaluated following methods by Pandini et al. (2015), with some modifications. The following bacteria used were: Escherichia coli (ATCC 25922), Pseudomonas aeruginosa (ATCC 27853), Proteus mirabilis (ATCC 25933), Klebsiella pneumoniae (ATCC 13883), Salmonella Enteritidis (ATCC 13076), Salmonella Gallinarum (ATCC 1138), 
Staphylococcus epidermidis (ATCC 12228), Staphylococcus aureus (ATCC 25923), Enterococcus faecalis (ATCC 19433) and Bacillus subtilis (CCD-04); the yeast Candida albicans (ATCC 10231) was also used. The microorganisms were recovered in brain heart infusion broth (BHI) and incubated for $24 \mathrm{~h}$ at $37{ }^{\circ} \mathrm{C}$. The final concentrations of the bacteria were standardized to $1 \times 10^{5}$ CFU.mL ${ }^{-1}$ in $0.85 \%$ saline solution.

The minimum inhibitory concentration (MIC) was determined according to the standards of the Clinical and Laboratory Standards Institute (2007) in 96-well microdilution plates. The essential oil was diluted to a concentration of $7000 \mu \mathrm{g} \cdot \mathrm{mL}^{-1}$. Briefly, an aliquot of $70 \mathrm{mg}$ essential oil was diluted in $1 \mathrm{~mL}$ of methanol (10\%). Then, $500 \mu \mathrm{L}$ solution was homogenized in $4.5 \mathrm{~mL}$ of Muller-Hinton broth $(\mathrm{MH})$. Serial dilutions ranged from 7000 to 3.4 $\mu \mathrm{g} . \mathrm{mL}^{-1}$. An aliquot of $10 \mu \mathrm{L}$ of each microorganism was added to the wells containing $150 \mu \mathrm{L}$ of $\mathrm{MH}$ broth and incubated for $24 \mathrm{~h}$ at 37 ${ }^{\circ} \mathrm{C}$. After the incubation period, $10 \mu \mathrm{L}$ of $1 \%$ triphenyl tetrazolium chloride (CTT) was added to each well and the microplates were incubated for additional three hours. The presence of red staining in the wells was interpreted as the absence of inhibitory effects of the essential oil.

The minimum bactericidal concentration (CBM) was determined by inoculating $10 \mu \mathrm{L}$ of the solution that was present in each well of the microdilution plates in Petri dishes containing $\mathrm{MH}$ agar. The plates were incubated for $24 \mathrm{~h}$ at $37^{\circ} \mathrm{C}$. As a positive control, gentamicin (bacteria) and nystatin (C. albicans) were used at $30 \mathrm{mg} \cdot \mathrm{mL}^{-1}$. The CIM and CBM were performed in triplicate and classified according to the criteria proposed by Sartoratto et al. (2004) as having low activity (7.000-3.500 $\left.\mu \mathrm{g} . \mathrm{mL}^{-1}\right)$, moderate activity (1.700-875 $\mu \mathrm{g} . \mathrm{mL}^{-1}$ ), high activity (437.5 to $218.75 \mu \mathrm{g} \cdot \mathrm{mL}^{-1}$ ) or very high activity $\left(<109.375 \mu \mathrm{g} \cdot \mathrm{mL}^{-1}\right)$.

\section{Antioxidant activity}

The antioxidant activity of the essential oils was measured by the DPPH (2,2-diphenyl-1-picryl hydrazyl) free radical method (SCHERER et al, 2009; WEBER et al, 2014.). Briefly, a $0.1 \mathrm{~mL}$ aliquot of the $7.000 \mu \mathrm{g} \cdot \mathrm{mL}^{-1}$ essential oil was treated with $3.9 \mathrm{~mL}$ of $50 \%$ methanol solution and homogenized in a tube shaker. The sample absorbances were measured in a spectrophotometer at $515 \mathrm{~nm}$. As a negative control, a solution composed of methanol, acetone and water $(40 \mathrm{~mL}$ of $70 \%$ acetone solution, $40 \mathrm{~mL}$ of $50 \%$ methanol solution and $20 \mathrm{~mL}$ distilled water) was added with DPPH. As a positive control, the commercial synthetic antioxidant butyl hydroxyl toluene (BHT) was used; $50 \%$ methanol was used for calibration.

The absorbance of DPPH was determined at concentrations of 34, 64, 100,134, 166 and $200 \mu \mathrm{m}$ $(\lambda=515 \mathrm{~nm})$ to determine the linear function of the data dispersion (i.e., the DPPH absorbances).

The antioxidant activity was calculated as follows: the DPPH straight line equation was initially calculated (linear function). The sequestration rate of DPPH for essential oil and BHT (positive control) was calculated by the following equation: $\mathrm{AA} \%=[(\mathrm{Abs} 0-\mathrm{Abs} 1) / \mathrm{Abs} 0]$ $\mathrm{x} 100$; where $\mathrm{Abs} 0$ is the absorbance of the negative control and Abs1 is the absorbance of the sample. The oil concentration required to reduce $50 \%$ of the DPPH free radical (IC50) was calculated by the absorbances of the different DPPH concentrations, which generated a linear function. The absorbance values were analyzed by the Chi-square test with a significance level of 0.05 . Statistical analyses were performed using the statistical software $\mathrm{R} \circledast$ version 3.3.2.

\section{Fumigation test of $M$. oblongata essential oil on D. gallinae}

The mites were collected in a commercial aviary located in the city of Medianeira, PR, Brazil and transported to the Laboratory of Agricultural Biotechnology at Unioeste in Cascavel. Only the engorged females were separated for the fumigation tests. The mites were used up to 3 days after collection.

The fumigation test was performed according to methodology proposed by Locher et al. (2010) and Tabari et al. (2015). The essential oil was diluted in acetone $10 \%$ at four concentrations: $10 \%, 5 \%, 2.5 \%$ and $1.25 \%$, with five replicates of 20 mites at each concentration. The control negative was performed with distilled water and $10 \%$ acetone. As a positive control we used triazophos (Hostathion) (COSTA et al., 2003). Twenty mites were placed in a carton $(1 \mathrm{~cm} \mathrm{x} 1 \mathrm{~cm})$ and then in an Eppendorf tube $(2 \mathrm{~mL})$ with the cap cut off. The tube opening was closed with voile fabric and tied with elastic. Each tube was placed in a flat glass bottom tube $(4 \mathrm{~cm} \times 7 \mathrm{~cm})$ and sealed with parafilm to prevent the loss of volatiles from the oil. Each flat bottom tube contained a piece of Whatman no. 2 filter paper $(2 \mathrm{~cm} \times 2 \mathrm{~cm})$ containing $50 \mu \mathrm{L}$ of the essential oil or control solution. This method prevented direct contact of the mite with the filter paper. The mites were conditioned in a BOD $\left(27^{\circ} \pm\right.$ $2{ }^{\circ} \mathrm{C}, 14 \mathrm{~h}$ photophase and $70 \%$ R.H.) room and after $24 \mathrm{~h}$, mortality rates were analyzed. The mites that did not move when touched with a fine-bristle 
brush were considered dead. Analysis of variance (ANOVA) was used to test for differences in mortality between treatments groups and controls with a significance level of 0.05 , and the Tukey test was used for comparisons of means. Statistical analyses were performed using the statistical software $R \circledR$ version 3.3.2.

\section{M. oblongata essential oil as a repellent for $D$. gallinae}

Repellency tests were carried out in a climate-controlled room with a temperature of $23 \pm$ $2{ }^{\circ} \mathrm{C}$ and $70 \%$ R.H. in dark phase because $D$. gallinae mites present nocturnal habits and during the day remain aggregated and hidden. In order to observe the behavior of mites, a red lightbulb ( $15 \mathrm{w}$, $100 \mathrm{v})$ was used because it does not interfere with vision in arthropods (EIRAS; MAFRA-NETO, 2001).

To evaluate whether the essential oils repelled mites, an experiment was carried out with Y olfactometer (EIRAS ; MAFRA NETO, 2001). The olfactometer consisted of a Y-shaped glass tube $(22 \times 14 \times 2 \mathrm{~cm})$ containing a main tube and two side tubes (arms) forming an angle of $120^{\circ}$ with the main tube. The olfactometer was operated with a continuous air flow of $3 \mathrm{~L} \cdot \mathrm{min}^{-1}$, and was previously humidified and filtered with activated charcoal. Pieces of filter paper cut into rectangles $(1 \times 4 \mathrm{~cm})$ and impregnated with $10 \mu \mathrm{L}$ of the control (ethanol P.A.) or $10 \mu \mathrm{L}$ of the essencial oil diluted in three different concentrations were placed in the side tubes. Detergent was applied by brushing to the lower end of the main tube to prevent the mites from escaping.

Three essential oil concentrations were evaluated: $10 \%, 5 \%$ and $1 \%$, using P.A. ethanol as solvent. For each oil concentration, 30 replicates were performed with five mites. The behavior of the mites was observed for 5 minutes. The time needed for mites to reach the source of odor was recorded, and if no mites chose one of the sources, the test was stopped and the mites were discarded. Only the repetitions in which the mites chose one of the sources of odor were considered. Every 5 replicates, the olfactometer was washed, oven dried at $60{ }^{\circ} \mathrm{C}$, and the position of the arm containing the control or repellent was inverted to avoid any influence of the external environment.

The choice of odor source was analyzed statistically using a Chi-square test with a significance level of 0.05 . The time the mites took to reach the odor source was analyzed using an independent-samples t-test $(\mathrm{p}=0.05)$. Statistical analyses were performed using the statistical software $R \circledR$ version 3.3.2.

\section{RESULTS AND DISCUSSION}

\section{GC-MS}

The chemical composition of the essential oil extracted from the leaves of $M$. oblongata revealed 30 compounds, representing $82.63 \%$ of the total area of the essential oil of the sample analysed, the main compounds obtained were caryophyllene oxide $(22.03 \%)$ and the trans-verbenol (11.94\%). It is important to note that the test of GC-MS is not able to quantify all the compounds present in the essential oil. Caryophyllene oxide is a bicyclic sesquiterpene, whereas trans-verbenol is a compound resulting from the bioconversion of $\square$ pinene (SOUZA et al., 2011), the third most abundant compound $(6.65 \%)$. These compounds are also present in many of the Myrtaceae (LIMBERGER et al., 2004), such as Myrcia salzmannii (CERQUEIRA et al., 2009), Myrcia obtecta, Myrcia hatschbachii and Myrcia arborescens (LIMBERGER et al., 2004).

Table 1. Chemical composition of essential oil extracted from M. oblongata leaves.

\begin{tabular}{lllllll}
\hline $\mathbf{N}^{\mathbf{0}}$ & Compounds & Class of compounds & $\begin{array}{l}\mathbf{T r}{ }^{a} \\
(\mathbf{m i n})\end{array}$ & $\begin{array}{l}\text { Area } \\
(\boldsymbol{\%})\end{array}$ & $\mathbf{I}_{\mathbf{R}}{ }^{b}$ & $* \mathbf{I}_{\mathbf{R}}{ }^{c}$ \\
\hline 1 & --Pinene & Monoterpene & 7.39 & 6.65 & 945 & 942 \\
2 & Camphene & Monoterpene & 7.98 & 0.12 & 962 & 958 \\
3 & 2,4-tujadiene & Monoterpene & 8.12 & 0.44 & 966 & 959 \\
4 & P-cymene & Monoterpene & 10.91 & 0.27 & 1038 & 1033 \\
5 & Crisantenone & $\begin{array}{l}\text { Monoterpene } \\
\text { Oxygenated }\end{array}$ & 15.11 & 0.28 & 1134 & 1131 \\
6 & $\alpha$-Campholenal & 15.37 & 0.37 & 1140 & 1130 \\
7 & L-pinocarveol & $\begin{array}{l}\text { Oxygenated } \\
\text { monoterpene }\end{array}$ & 15.96 & 0.98 & 1153 & 1154 \\
8 & Cis-verbenol & $\begin{array}{l}\text { Oxygenated } \\
\text { monoterpene }\end{array}$ & 16.04 & 1.52 & 1154 & 1142 \\
9 & $* *$ Trans-verbenol & Oxygenated & 16.21 & 11.94 & 1158 & 1150
\end{tabular}




\begin{tabular}{|c|c|c|c|c|c|c|}
\hline & & & & & & \\
\hline 10 & Pinocarvone & & 16.93 & 0.52 & 1173 & 1168 \\
\hline 11 & $\alpha$-Felandren-8-ol & $\begin{array}{l}\text { Oxygenated } \\
\text { monoterpene }\end{array}$ & 17.44 & 1.80 & 1185 & 1170 \\
\hline 12 & Mirtenol & $\begin{array}{l}\text { Oxygenated } \\
\text { monoterpene }\end{array}$ & 18.49 & 0.75 & 1208 & 1202 \\
\hline 13 & Cis-verbenone & $\begin{array}{l}\text { Oxygenated } \\
\text { monoterpene }\end{array}$ & 18.96 & 3.32 & 1218 & 1218 \\
\hline 14 & Trans-carveol & $\begin{array}{l}\text { Oxygenated } \\
\text { monoterpene }\end{array}$ & 19.63 & 0.31 & 1233 & 1229 \\
\hline 15 & $\alpha$-Cubebene & Hydrocarbon & 25.13 & 0.36 & 1356 & 1355 \\
\hline 16 & $\alpha$-Copaene & $\begin{array}{l}\text { Sesquiterpene } \\
\text { hydrocarbon }\end{array}$ & 26.33 & 1.12 & 1384 & 1383 \\
\hline 17 & $\beta$-Cubebene & $\begin{array}{l}\text { Sesquiterpene } \\
\text { hydrocarbon }\end{array}$ & 26.87 & 0.37 & 1396 & 1392 \\
\hline 18 & $\beta$-Caryophyllene & $\begin{array}{l}\text { Sesquiterpene } \\
\text { hydrocarbon }\end{array}$ & 28.16 & 3.70 & 1426 & 1428 \\
\hline 19 & $\begin{array}{l}\text { (+)-Epi- } \\
\text { bicyclosesquipelandene }\end{array}$ & $\begin{array}{l}\text { Sesquiterpene } \\
\text { hydrocarbon }\end{array}$ & 29.39 & 0.35 & 1456 & 1470 \\
\hline 20 & $\alpha$-Caryophyllene & $\begin{array}{l}\text { Sesquiterpene } \\
\text { hydrocarbon }\end{array}$ & 29.65 & 0.70 & 1462 & 1458 \\
\hline 21 & $\underline{(+) \text {-Aromadendrene }}$ & $\begin{array}{l}\text { Sesquiterpene } \\
\text { hydrocarbon }\end{array}$ & 29.81 & 0.46 & 1466 & 1463 \\
\hline 22 & $\beta$-eudesmane & $\begin{array}{l}\text { Sesquiterpene } \\
\text { hydrocarbon }\end{array}$ & 31.03 & 3.47 & 1495 & 1496 \\
\hline 23 & Elixene & $\begin{array}{l}\text { Sesquiterpene } \\
\text { hydrocarbon }\end{array}$ & 31.30 & 2.66 & 1502 & 1511 \\
\hline 24 & $\square$-Cadinene & $\begin{array}{l}\text { Sesquiterpene } \\
\text { hydrocarbon }\end{array}$ & 32.25 & 2.94 & 1525 & 1524 \\
\hline 25 & Calamene & $\begin{array}{l}\text { Sesquiterpene } \\
\text { hydrocarbon }\end{array}$ & 32.37 & 3.11 & 1528 & 1529 \\
\hline 26 & $\alpha$-Calacorene & $\begin{array}{l}\text { Sesquiterpene } \\
\text { hydrocarbon }\end{array}$ & 33.14 & 1.30 & 1548 & 1548 \\
\hline 27 & Caryophyllene alcohol & $\begin{array}{l}\text { Oxygenated } \\
\text { sesquiterpene }\end{array}$ & 33.49 & 2.04 & 1557 & 1563 \\
\hline 28 & (-) - Espatulenol & $\begin{array}{l}\text { Oxygenated } \\
\text { sesquiterpene }\end{array}$ & 34.53 & 4.22 & 1583 & 1582 \\
\hline 29 & Caryophyllene oxide & $\begin{array}{l}\text { Oxygenated } \\
\text { sesquiterpene }\end{array}$ & 34.69 & 22.03 & 1587 & 1583 \\
\hline 30 & Humulene Epoxide II & $\begin{array}{l}\text { Oxygenated } \\
\text { sesquiterpene }\end{array}$ & 35.76 & 2.75 & 1614 & 1607 \\
\hline & TOTAL & & 41.60 & $82,63 \%$ & & \\
\hline & Monoterpenes & & & $7.76 \%$ & & \\
\hline & $\begin{array}{l}\text { Oxygenated } \\
\text { monoterpene }\end{array}$ & & & $21.51 \%$ & & \\
\hline & Sesquiterpene & & & $20.54 \%$ & & \\
\hline & $\begin{array}{l}\text { Oxygenated } \\
\text { sesquiterpene }\end{array}$ & & & $32.82 \%$ & & \\
\hline
\end{tabular}

${ }^{a} T_{R}$ : retention time; ${ }^{b} I_{R}$ : calculated retention index values; ${ }^{c} * I_{R}:$ retention index values from NIST/EPA/NIH Mass Spectral Library, version $2.0 \mathrm{~d}$, april 2005

Comparison of data from the present study with the data described in the literature revealed a variation in the number of compounds present in the essential oil of $M$. oblongata (Table 1) when compared to other species of the Myrtaceae family. This variation may be attributed to environmental 
variables such as leaf collection time, circadian rhythm, plant development, temperature, water availability, ultraviolet radiation, soil nutrient content, altitude, pollution, and pathogen attack, among other factors (GOBBO-NETO; LOPES, 2007). These variables demonstrate a significant influence of external factors on the composition of essential oils (DUDAREVA et al., 2004).

Essential oils of 17 species of the genus Myrcia were studied and there was predominance of cyclic sesquiterpenes (CERQUEIRA et al., 2007; SILVA et al., 2007; STEFANELLO et al., 2010), except in Myrcia myrtifolia, Myrcia acuminatissima and Myrcia bombycina whose levels of monoterpenes were more abundant (CERQUEIRA et al., 2009; HENRIQUES et al., 2011) the oil of $M$. oblongata presented significant amounts of sesquiterpenes and monoterpenes, as well as the species of the same family.

Caryophyllene derivatives have been identified in large numbers in M. oblongata in this work and also by other authors, this substance has also been isolated in species of the same genus, such as Myrcia acuminatissima, Myrcia alagoensis, Myrcia arborescens, Myrcia cuprea, Myrcia fallax, Myrcia glabra, Myrcia hatschbachii, Myrcia multiflora, Myrcia pubiflora, Myrcia pubipetala,
Myrcia richardiana, Myrcia rostrata, Myrcia rufipila, Myrcia salzmannii, Myrcia selloii and Myrcia splendens. Derived from the terpene pinene were also isolated in most of these species, but the compound verbenol was only identified in $M$. oblongata (CASCAES et al., 2015).

\section{Antimicrobial activity}

The MIC and MBC of $M$. oblongata essential oils for microorganisms ranged from 218.75 to $7.000 \mu \mathrm{g} \cdot \mathrm{mL}^{-1}$ (Table 2). The best results were observed for Gram-positive bacteria, with the highest inhibitory and bactericidal activity for $E$. faecalis (MIC / MBC: 218.75 / $875 \mu \mathrm{g} \cdot \mathrm{mL}^{-1}$ ), followed by $S$. aureus and B. subtillis, both with MIC 875 and MBC $1.700 \mu \mathrm{g} \cdot \mathrm{mL}^{-1}$, and $S$. epidermidis $\left(1,700 / 1,700 \mu \mathrm{g} \cdot \mathrm{mL}^{-1}\right)$. The activity against Gram-negative bacteria was considered low, with the best result for E. coli (MIB and MCB = $7,000 \mu \mathrm{g} \cdot \mathrm{mL}^{-1}$ ), followed by $P$. aeruginosa and $S$. enteritidis, both with MIC of 7,000 $\mu \mathrm{g} . \mathrm{mL}^{-1}$ and no activity for MBC. No activity was observed for $P$. mirabilis, $K$. pneumoniae and $S$. Gallinarum. For $C$. albicans, minimal fungicidal and inhibitory activity (MIC and MBC, respectively) were both observed at $3,500 \mu \mathrm{g} \cdot \mathrm{mL}^{-1}$.

Table 2. Minimum inhibitory concentration (MIC), minimum bactericidal concentration (MBC) and minimum fungicidal concentration (CFM) of M. oblongata essential oil against standard microorganisms.

\begin{tabular}{lc}
\hline Microorganism & MIC/MIB or MFC $\left(\mu \mathrm{g} \cdot \mathrm{mL}^{-1}\right)$ \\
\hline Gram-negative & $7000 / 7000$ \\
E. coli & $7000 /-$ \\
P. aeruginosa & - \\
P. mirabilis & - \\
K. pneumoniae & $7000 /-$ \\
S. Enteritidis & - \\
S. Gallinarum & \\
\hline
\end{tabular}

\section{Gram-positive}

S. epidermidis

$1700 / 1700$

S. aureus

$875 / 1700$

E. faecalis

$218.75 / 875$

B. subtilis

$875 / 1700$

\section{Fungi}

C. albicans

$3500 / 3500$

The activity of the essential oils against $C$. albicans was considered low. There are no reports in the literature for plants of the same genus, but similar results have been found for Eucalyptus 
citriodora and Eugenia uniflora, which also belong to the family Myrtaceae. The essential oils from the leaves of these plants were tested on different species of Candida and presented moderate and low activity (LIMA et al., 2006; CASTRO; LIMA, 2010). The low susceptibility of the fungal cells to the essential oil may be due to the low hydrophobicity of the chemical constituents. The lower the hydrophobicity, the lower the permeability of the oil into the cell, and this decreases the efficacy of the essential oil (PRABUSEENIVASAN et al., 2006).

Gram-positive bacteria were more susceptible to the action of essential oils than Gramnegative bacteria. This was also observed for the essential oils of Myrcia tomentosa and Myrcia myrtifolia, which showed activity against B. subtilis, $S$. aureus and other Gram-positive bacteria (SÁ et al., 2012; YOKOMIZO; NAKAOKA-SAKITA, 2014; SIMONETTI et al., 2016). This susceptibility of Gram-positive bacteria can be explained by the presence of a bacterial cell wall that does not restrict the penetration of toxic molecules, whereas Gramnegative bacteria have a barrier system in the outer membrane of the bacterial wall formed by phospholipids, lipopolysaccharides and proteins that are impermeable to many microorganisms (LAMBERT, 2002; MADIGAN et al., 2010).

\section{Antioxidant activity}

The DPPH free radical sequestration index presented as linear function with the equation $\mathrm{y}=$ 0.0105. $\mathrm{x}-0.0249$. The absorbances (for essential oil and BHT) were analyzed by the chi-square test for adherence, with significance level of 0.05 . We found no significant statistical difference between the absorbances of the positive control (BHT) and the essential oil of $M$. oblongata $(\chi 2=0.21356$; GL $=1 ; \mathrm{p}=0.644)$. The was also no significant statistical difference in IC50 $(\chi 2=1.8639, \mathrm{GL}=1, \mathrm{p}$ $=0.1722$ ).

Although the essential oil of $M$. oblongata did not present antioxidant activity as high as BHT according to the classification of Scherer et al. (2009), it has moderate activity in this same classification, indicating that this oil at the concentration of $7,000 \mu \mathrm{g} \cdot \mathrm{mL}^{-1}$ has antioxidant potential.

The percentages of DPPH sequestration through the absorbance equation and the IC50 are shown in Table 3. The percentage of DPPH sequestration was $88.33 \%$ and the IC50 was 2.80 for the essential oil, while those values were $94.58 \%$ and 1.39 , respectively, for BHT .

Table 3. Antioxidant activity of essential oil from the leaves of M. oblongata

\begin{tabular}{ccc}
\hline Test Solution & $\begin{array}{c}\text { \% Sequestration of } \\
\text { DPPH }\end{array}$ & IC $_{\mathbf{5 0}}$ \\
\hline Positive control (BHT) & $94.58 \%$ & 1.39 \\
M. oblongata essential oil & $88.33 \%$ & 2.80
\end{tabular}

$\mathrm{BHT}=$ synthetic commercial antioxidant; $\mathrm{DPPH}=2$ 2,-diphenyl-1-picrylhydrazyl; $\mathrm{IC}_{50}=$ concentration of oil required to reduce DPPH radicals by $50 \%$.

The antioxidant activity of Myrcia spp. were verified in the literature for Myrcia splendens, Myrcia bella and Myrcia lingua, and in the family (Myrtaceae) for Blepharocalyx salicifolius, Eugeni bimarginata, Eugenia dysenterica, Eugenia klotzschiana, Hexachlamys edulis, Psidium australe, Psidium cinereum, Psidium laruotteanum and Psydium guajava; all these species have high or moderate antioxidant activity (TAKAO et al., 2015) as $\operatorname{did}$ M. oblongata in this study.

The antioxidant potential of Myrtaceae species may be associated with the presence of caryophyllenes, verbenols and phenolic compounds, whose antioxidant activity has been verified through various chromatographic techniques (SHAHIDI et al., 1992). However, the results of antioxidant activity assays reported in the literature cannot always be directly compared since different methods generate different responses (MOLYNEUX, 2004). Among the most commonly used methods, the free radical DPPH reduction method used in this study is as a faster and less expensive alternative compared to other common spectrophotometry techniques (MOLYNEUX, 2004; ALVES et al., 2010). The spectrophotometer used in this study was composed of the radiation source of tungsten filament lamp, a monochromator, the sample holder (quartz cuvettes) and the coupled charge devices.

\section{M. oblongata essential oil fumigation of $D$. gallinae}

Comparison of means of the four concentrations (10\%, 5\%, 2.5\% and $1.25 \%)$ of essential oil showed no significant differences from 
control negative according to the Tukey test $(\mathrm{F}=$ $0.21, \mathrm{p}=0.92, \mathrm{GL}=4)$. The positive control, triazophos, killed $100 \%$ of the mites. All essential oil concentrations resulted in mortality lower than $20 \%$ (Table 4). Similar results were observed for Eugenia uniflora (Myrtaceae), which did not cause significant mortality for Ornithonyssus bursa (Acari: Dermanyssidae) after fumigation treatment (VILLAÇA, 2012). There are currently no reports of activity against pests after fumigation with essential oils for any species of the genus Myrcia.

Table 4. Fumigation with different concentration of M. oblongata essential oil against D. gallinae $(\mathrm{n}=100)$.

\begin{tabular}{ccccccc}
\hline & $\begin{array}{c}\text { Control } \\
\text { water, Tween and } \\
\text { 10\% acetone) }\end{array}$ & & $\mathbf{1 0 \%}$ & $\mathbf{5 \%}$ & $\mathbf{1 . 2 5 \%}$ \\
\hline Mean number & $0.6 \sim 1 \pm 0.5 \mathrm{a}$ & $3.8 \sim 4 \pm 1.8$ & $2.4 \sim 3 \pm 1.8$ & $2.4 \sim 3 \pm 2.6$ & $2 \pm 1.7 \mathrm{a}$ \\
Mortality (\%) & 5 & $\mathrm{a}$ & $\mathrm{a}$ & $\mathrm{a}$ & \\
\end{tabular}

Means \pm standard deviation of mite mortality at $24 \mathrm{~h}$. Values followed by the same letter do not differ other according to the Tukey test.

However, the exposure time of the mites in this experiment was $24 \mathrm{~h}$ and according to Pauliquevis and Fávero (2015), lethal effects of fumigation may be related to the time of exposure to essential oil; these authors found no mortality in mites fumigated with essential oil of Eucalyptus urograndis (Myrtaceae) after 24h, but did observe mortality after $48 \mathrm{~h}$. Although the fumigation test in this experiment resulted in mortality lower than $20 \%$, acaricides with plant essential oils as the active ingredients are already available on the market. These products are mainly obtained from plants of the family Myrtaceae such as Syzygium aromaticum (ISMAN, 2010). The volatility of the essential oils has proven fumigant action and may serve as an alternative to conventional acaricides (ASLAN et al., 2004). However, the type of application influences the effectiveness against mites, and for this reason different methods of application of essential oils and the resulting acaricidal effects should be investigated for $M$. oblongata.

\section{Repellency of $M$. oblongata essential oil against D. gallinae}

The activity of $M$. oblongata essential oil as a repellent for chicken mites was analyzed at three different concentrations and was evaluated according to the number of responses (Chi-square goodness-of-fit test) and response time (independent-samples t-test). At concentrations of $1 \%$ and $5 \%$, the number of mites attracted to the essential oil was similar to that of the control (1\%: $\chi 2=0.926, \mathrm{GL}=1, \mathrm{p}=0.336 ; 5 \%: \chi 2=3.24, \mathrm{GL}$ $=1, \mathrm{p}=0.0719)$ (Table 5). These concentrations also led to similar average times between treatments $(\mathrm{t}=1.52, \mathrm{p}=0.93)$ and controls $(\mathrm{t}=$ $2.51, \mathrm{p}=0.99$ ). These results demonstrate that at the lowest concentrations, the essential oil did not repel mites. At the $10 \%$ concentration, there was also no statistical difference in response time between the control and oil treatment $(\mathrm{t}=2.78, \mathrm{p}$ $=0.99)$. However, there were fewer mites attracted to the essential oil (5) than to the control (17) $(\chi 2=6,545 ; \mathrm{GL}=1 ; \mathrm{p}=0.0105)$. This result demonstrates the repellent action potential of $M$. oblongata essential oil at $10 \%$ concentration.

Table 5. Total number of D. gallinae females attracted to an odor source and mean time (h: m: s) to choosing $\mathrm{Y}$-olfactometer arms for three concentrations of M. oblongata essential oil $(\mathrm{n}=150)$.

\begin{tabular}{ccc}
\hline & $\begin{array}{c}\text { Total number of } \\
\text { responses }\end{array}$ & Time (h:m:s) \\
\hline Control & 16 & $00: 45: 16$ \\
Essential oil 1\% & 10 & $00: 26: 24$ \\
Control & 17 & $00: 41: 12$ \\
Essential oil 5\% & 8 & $00: 15: 59$ \\
Control & $17^{*}$ & $00: 45: 54$ \\
Essential oil 10\% & 5 & $00: 15: 07$
\end{tabular}

\footnotetext{
*Indicated a statistically significant difference in the number of responses between the control and essential oil treatment (Chi-square
} test, $\mathrm{p}<0.05)$. For time, there were no statistically significant differences between any treatments $(\mathrm{t}-\mathrm{test}, \mathrm{p}>0.05)$. 
George et al., (2009) evaluated the acaricidal activity of essential oils of four species of Myrtaceae on D. gallinae: Eucalyptus globulus, Eucalyptus radiata, Eucalyptus staigeriana and Eucalyptus citriodora. The authors found that oils with the highest activity had a greater number of chemical constituents in their composition. The species $M$. oblongata, tested in the present work, contains 30 compounds (Table 1) that can interact and that repel the mites. In addition, the activity of terpenes such as $\delta$-pinene and caryophyllene oxide, the latter being one of the major compounds of $M$. oblongata, are known to act as repellents against Sitophilus zeamais, Tribolium confusum (Coleoptera: Curculionidae) and the mite Tetranichus urticae (Acari: Tetranychidae) (TAPONDJOU et al., 2005; LIMA et al., 2009).

\section{CONCLUSIONS}

We identified 30 chemical compounds in the essential oil of $M$. oblongata, with caryophyllene oxide $(22.03 \%)$ and trans-verbenol $(11.94 \%)$ as the majority constituents.

The antimicrobial activity of the essential oil was higher for Gram-positive bacteria than for Gram-negative bacteria. The highest activity was against $E$. faecalis, followed by $S$. aureus, $B$. subtillis and S. epidermidis.

The antimicrobial activity against Gramnegative bacteria was considered low, with the best results observed for $E$. coli, $P$. aeruginosa, and S. Enteritidis. The oil showed no activity against $P$. mirabilis, $K$. pneumoniae and $S$. Gallinarum. Activity against $C$. albicans was also considered low. At a concentration of 7,000 $\mu \mathrm{g} . \mathrm{mL}^{-1}$, the oil showed antioxidant potential and repellent potential against D. gallinae at $10 \%$ concentration, but did not repel mites when applied at concentrations below $10 \%$.

The fumigation test of $M$. oblongata on $D$. gallinae showed that essential oil concentrations between $1.25 \%$ and $10 \%$ promoted low mortality.

\section{ACKNOWLEDGEMENTS}

The authors thank CAPES (government agency linked to the Brazilian Ministry of Education in charge of promoting high standards for postgraduate courses in Brazil), the Araucária Foundation and $\mathrm{CNPq}$ (National Council for Scientific and Technological Development) for their financial support.

RESUMO: Os óleos essenciais tem despertado interesse no setor industrial por apresentarem multiplicidade de aplicações, destacando-se por suas propriedades antimicrobianas, antioxidantes dentre outras. Diante disto, o objetivo deste estudo foi determinar a composição química do óleo essencial das folhas de Myrcia oblongata DC pelo método de cromatografia gasosa acoplada à espectrometria de massas (CG-EM), avaliar o potencial antioxidante do óleo pelo método de captura do radical livre 2,2- difenil-1-picril hidrazil (DPPH), testar a atividade antimicrobiana pelo método de microdiluição em caldo, bem como avaliar a repelência e potencial fumigante deste óleo sobre Dermanyssus gallinae (Degeer, 1778). As análises de CG-EM resultaram na identificação de 30 constituintes, sendo majoritários o óxido de cariofileno (22.03\%) e o trans-verbenol (11.94\%). O óleo apresentou atividade antioxidante moderada quando comparada ao antioxidante sintético 2,6-di-tert-butil-4-hidroxitolueno (BHT). Em relação à atividade antimicrobiana, o óleo essencial demonstrou atividade inibitória para as bactérias Gram-positivas, Enterococcus faecalis, Staphylococcus aureus, Bacillus subtilis e Staphylococcus epidermidis, e para levedura Candida albicans e não apresentou atividade para bactérias Gram negativas. Todas as concentrações do óleo essencial testadas no teste de fumigação sobre $D$. gallinae apresentaram mortalidade inferior a 20\%. Para o teste de repelência, observou-se um potencial significativo para a concentração de $10 \%$.

PALAVRAS-CHAVE: CG-EM. óxido de cariofileno. Dermanyssus gallinae

\section{REFERENCES}

ACIOLE, Sullamy Dayse Gomes. Avaliação da atividade inseticida dos óleos essenciais das plantas Amazônicas Annonaceae Boraginaceae e de Mata Atlântica Myrtaceae como alternativa de controle as larvas de Aedes aegypti (Linnaeus, 1762) (Diptera Culicidae). 2001. 72f. Dissertação (Mestrado em Biologia Humana e Ambiental) - Curso de Pós-Graduação em Biologia Humana e Ambiental, Universidade de Lisboa, Lisboa, 2001. 
ADAMS, R. P. Identificação de componentes de óleos essenciais por cromatografia gasosa / espectrometria de massa. Londres: Allured Pub. Corp, 2007. 804 p.

ALVES, C. Q.; DAVID, J. M.; BAHIA, M. V.; AGUIAR, R. M. Métodos para determinação de atividade antioxidante in vitro em substratos orgânicos. Química Nova, v. 33, n. 10, p. 2202-2210, 2010. http://www.repositorio.ufba.br/ri/handle/ri/3769 https://doi.org/10.1590/S0100-40422010001000033

ASLAN, I.; OZBEK, H.; KORDALI, S.; CALMASUR, O.; ÇAKIR A. Toxicity of essential oil vapours obtained from Pistacia spp. to the granary weevil, Sitophilus granarius (L.) (Coleoptera: Curculionidae). Journal of Plants Diseases Protection, v. 111, n. 4, p. 400-407, 2004.

BASER, K. H. C. and BUCHBAUER, G. Handbook of Essential Oils: Science, Technology, and Applications. 2. ed. CRC Press, 2015. 1112 p.

BURT, S. Essential oils: their antibacterial properties and potential applications in foods - a review. International Journal of Food Microbiology, v. 94, p. 223-253, 2004. https://doi.org/10.1016/j.ijfoodmicro.2004.03.022

CASCAES, M. M.; GUILHON, G. M. S. P.; ANDRADE, E. H. A. DE; ZOGHBI, M. G. B; SANTOS, L, S. Constituents and Pharmacological Activities of Myrcia (Myrtaceae): A Review of an Aromatic and Medicinal Group of Plants. Journal of Mololecular Sciences, v. 16, p. 23881-23904, 2015.

file:///C:/Users/Seven/Downloads/ReviewMyrcea\%20(1).pdf

CASTRO, R. D. and LIMA, E. O. Atividade antifúngica in vitro do óleo essencial de Eucalyptus globulus L. sobre Candida spp. Revista de Odontologia da UNESP, v. 39, n. 3, p. 179-184, 2010.

CERQUEIRA, M. D. DE; SOUZA-NETA, L. C.; PASSOS, M. G. V. M.; LIMA, E. O.; ROQUE, N. F.; MARTINS, D.; GUEDES, M. L. S.; CRUZ, F. G. Seasonal Variation and Antimicrobial Activity of Myrcia myrtifolia Essential Oils. Journal of the Brazilian Chemical Society, v. 18, n. 5, p. 998-1003, 2007. http://dx.doi.org/10.1590/S0103-50532007000500018.

CERQUEIRA, M. D. DE; MARQUES, E. J. DE; MARTINS, D.; ROQUE, N. F.; CRUZ, F. G.; SILVA, M. L. DA. Variação sazonal da composição do óleo essencial de Myrcia salzmannii Berg. (Myrtaceae). Química Nova, v. 32, n. 6, p. 1544-1548, 2009. https://dx.doi.org/10.1590/S0100-40422009000600035

CEYHAN, N.; KESKIN, D.; UGUR, A. Antimicrobial activities of different extracts of eight plant spices from four different family against some pathogenic microorganisms. Journal of Food Agriculture and Environment, v. 10, p. 193-197, 2012. http://world-food.net/download/journals/2012-issue_1/f38.pdf

CIPRIANI A. F.; FIGUEIREDO, R. M.; SOARES, G. L. G.; KAPLAN, M. A. C. Implicações químicas na sistemática e filogenia de Bignoniaceae. Química Nova, v. 35, n. 11, p. 2125-2131, 2012. http://quimicanova.sbq.org.br/imagebank/pdf/Vol35No11_2125_04-AR12405.pdf https://doi.org/10.1590/S0100-40422012001100005

COSTA, N. M.; TEIXEIRA, C. A. D.; GARCIA, A.; SOUZA, M. S.; GAMA, F. CASTRO DE. Eficiência de acaricidas no controle de ácaro-vermelho em café Conilon. Comunicado Técnico 270. Ministério da Agricultura, Pecuária e Abastecimento. ISSN 0103-9458, Porto Velho, RO. 2003.

DUDAREVA, N.; PICHERSKY, N.; GERSHENZON, J. Biochemistry of Plant Volatiles. Plant Physiology. v. 135 , p. 1893-1902, 2004. https://doi.org/10.1104/pp.104.049981

EIRAS, A. E. and MAFRA-NETO A. Olfatometria aplicada ao estudo do comportamento de insetos, p. 27-39. In: VILELA E. F. and DELLA L. M. T. (eds.), Feromônios de insetos: Biologia, química e emprego no manejo de pragas. Ribeirão Preto, 206p. 2001. 
SILVA, FABIANO G.; OLIVEIRA, C. B. A.; PINTO, J. E.B. P., NASCIMENTO, V. E.; SANTOS, S. C.; SERAPHIN, J. C.; FERRI, P. H. Seasonal Variability in the Essential Oils of Wild and Cultivated Baccharis trimera. Journal of the Brazilian Chemical Society, v. 18, n. 5, p. 990-997, 2007. http://dx.doi.org/10.1590/S0103-50532007000500017

GEORGE, D. R.; MASIC, D.; OLIVIER, A. E.; SPARAGNO, J. H. G. Variation in chemical composition and acaricidal activity against Dermanyssus gallinae of four eucalyptus essential oils. Sparagano Journal: Veterinary Parasitology, v. 48, p. 43-50, 2009. https://doi.org/10.1007/s10493-008-9225-z

GOBBO-NETO, L. and LOPES, N. P. Plantas medicinais: fatores de influência no conteúdo de metabólitos secundários. Química Nova, v. 30, n. 2, p. 374-381, 2007. https://doi.org/10.1590/S0100-40422007000200026

HENRIQUES, A. T.; SOBRAL M.; BRIDI, R.; VÉRIN, P.; MENUT, C.; GÉRARD LAMATY, G.; LESS, J. M. B. S. Essential Oils from Five Southern Brazilian Species of Myrcia (Myrtaceae). Journal of Essencial Oil Research, v. 9, p. 13-18, 2011. https://doi.org/10.1080/10412905.1997.9700707

ISMAN, M. B. Botanical insecticides, deterrents, and repellents in modern agriculture and an increasingly regulated world. Annual Review of Entomology, v. 51, p. 45-66, 2010.

https://doi.org/10.1146/annurev.ento.51.110104.151146

KASPER, D. L. and FAUCI, A. S. Doenças Infecciosas de Harrison. 2 ed. Artmed: Mc Graw Hill Education. 2015.

LAMBERT, P. A. Cellular impermeability and uptake of biocides and antibiotics in Gram-positive bactéria and mycobacteria. Journal of Applied Microbiology, v. 92, p. 46-54, 2002. https://doi.org/10.1046/j.13652672.92.5s1.7.x

LIMA, I. O.; OLIVEIRA, R. A. G.; LIMA, E. O.; FARIAS, N. M. P.; SOUZA, E. L. Atividade antifúngica de óleos essenciais sobre espécies de Candida. Brazilian Journal of Pharmacognosy, v. 16, n. 2, p. 197-201, 2006. https://doi.org/10.1590/S0102-695X2006000200011

LIMA, R. K.; CARDOSO, M. G.; MORAES, J. C.; MELO, B. A.; RODRIGUES, V. G.; GUIMARÃES, P. L. Atividade inseticida do óleo essencial de pimenta longa (Piper hispidinervum C. DC.) sobre lagarta-docartucho do milho Spodoptera frugiperda (J. E. 98 Smith, 1797) (Lepidoptera: Noctuidae). Acta Amazonica, v. 39, n. 2, p. 377-382, 2009. https://doi.org/10.1590/S0044-59672009000200016

LIMBERGER R. P.; SOBRAL, M.; HENRIQUES A. T. Óleos voláteis de espécies de Myrcia nativas do Rio Grande do Sul. Química Nova, v. 27, n. 6, p. 916-919, 2004.

http://www.scielo.br/pdf/\%0D/qn/v27n6/22281.pdf https://doi.org/10.1590/S0100-40422004000600015

LOCHER, N.; KHALED, A. S.; ABDEL-GHAFFAR, F.; MEHLHORN, H. In vitro and field studies on the contact and fumigant toxicity of a neem-product (Mite-Stop ${ }^{\circledR}$ ) against the developmental stages of the poultry red mite Dermanyssus gallinae. Parasitology Research, v. 107, p. 417- 423, 2010.

https://doi.org/10.1007/s00436-010-1882-2

MADIGAN, M. T.; MARTINKO, J. M.; DUNLAP, P. V.; CLARK, D. P. Microbiologia de Brock. 12. ed. Porto Alegre: Artmed, 2010. 1128 p.

MAHMOUDI, H.; AOUADHI, C.; KADDOUR, R.; GRUBER, M.; ZARGOUNI, H.; ZAOUAL, W.; BEN HAMIDA, N.; BEN NASRI, M.; OUERGHI, Z.; HOSNI, K. Comparison of antioxidant and antimicrobial activities of two cultivated cistus species from Tunisia. Biosciense Journal, v. 32, p. 226-237, 2016.

https://doi.org/10.14393/BJ-v32n1a2016-30208 
MOLYNEUX, P. The use of the stable free radical diphenylpicryl-hydrazyl (DPPH) for estimating antioxidant activity. Songklanakarin Journal of Science and Technology, v. 26, p.211-219, 2004.

https://pt.scribd.com/doc/153504289/DPPH-Oleh-Molyneux

MORS, W. B.; RIZZINI, C. T.; PEREIRA, N. A. Medicinal Plants of Brasil. Reference Publications, Inc. Algonac, Michigan, 2000. 501p.

OUSSALAH, M.; CAILLET, S.; SAUCIER, L.; LACROIX, M. Inhibitory effects of selected plant essential oils on the growth of four pathogenic bacteria: E.coli O157:H7, Salmonella Typhimurium, Staphylococcus aureus and Listeria monocytogenes. Food Control, v. 18, n. 5, p. 414-20, 2007. https://doi.org/10.1016/j.foodcont.2005.11.009

PALERMO, N. J., 2015 [24 abril 2015]. Web: Fatos e mitos sobre resistência bacteriana a antimicrobianos usados em produção animal [online]. Available from: http://facta.org.br/fatos-e-mitos-sobre-resistenciabacteriana-aantimicrobianos-usados-em-producao animal/

PANDINI, J. A.; PINTO, F. G. S.; SCUR, M. C.; ALVES, L. F. A.; MARTINS, C. C. Antimicrobial, insecticidal, and antioxidant activity of essential oil and extracts of Guarea kunthiana A. Juss. Journal of Medicinal Plants Research, v. 9, n. 17, p. 48-55, 2015.

PAULIQUEVIS, C. F. and FAVERO, S. Atividade insetistática de óleo essencial de Pothomorphe umbellata sobre Sitophilus zeamais. Revista Brasileira de Engenharia Agrícola e Ambiental, v. 19, n. 12, p. 11921196, 2015. https://doi.org/10.1590/1807-1929/agriambi.v19n12p1192-1196

PRABUSEENIVASAN S.; JAYAKUMAR, M.; IGNACIMUTHU, M. In vitro antibacterial activity of some plant essential oils. Journal of the International Society for Complementary Medicine Research, p. 6-39, 2006. https://doi.org/10.1186/1472-6882-6-39

ROSA, C. S.; VERAS, K. S.; SILVA, P. R.; LOPES NETO, J. J.; CARDOSO, H. L. M.; MAIA, J. G. S.; MONTEIRO, O. S.; MORAES, D. F. C. Composição química e toxicidade frente Aedes aegypti L. e Artemia salina Leach do óleo essencial das folhas de Myrcia sylvatica (G. Mey) DC. Revista Brasileira de Plantas Medicinais, v. 18, n. 1, p. 1-9, 2016. http://dx.doi.org/10.1590/1983-084X/15_006

SÁ, F. A. S.; BORGES, L. L.; PAULA, J. R.; SAMPAIO, B. L.; FERRI, P. H.; PAULA, J. R. Essential oils in aerial parts of Myrcia tomentosa : composition and variability. Revista Brasileira de Farmacognosia, v. 22, n. 6, p. 1233-1240, 2012. http://dx.doi.org/10.1590/S0102-695X2012005000120

SANTANA, Camila Beatriz. Composição química, atividade antimicrobiana, inseticida e antioxidante do óleo essencial e extratos de Myrcia oblongata

DC. 2017. 77 f. Dissertação (Mestrado em Conservação e Manejo de Recursos

Naturais) - Curso de Pós-Graduação em Conservação e Manejo de Recursos Naturais, Universidade Estadual do Oeste do Paraná, Cascavel, 2017.

SARTORATTO, A.; MACHADO, A. L. M.; DELARMELINA, C.; FIGUEIRA, G. M.; DUARTE, M. C. T.; REHDER, V. L. G. Composition and antimicrobial activity of essential oils from aromatic plants used in Brazil. Brazilian Journal of Microbiology, v. 35, n. 4, p. 275-280, 2004. http://dx.doi.org/10.1590/S151783822004000300001

SCHERER, R.; WAGNER, R.; DUARTE, M. C. T.; GODOY, H. T. Composition and antioxidant and antimicrobial activities of clove, citronella and palmarosa essential oil. Revista Brasileira de Plantas Medicinais, v. 11, n. 4, p. 442-449, 2009. http://dx.doi.org/10.1590/S1516-05722009000400013

SHAHIDI, F.; JANITHA, P. K.; WANASUNDARA, P. D. Phenolic antioxidants. Reviews in Food Science and Nutrition, v. 32, n. 1, p. 67-103, 1992. http://dx.doi.org/10.1080/10408399209527581 
SIMÕES, C. M. O.; SPITZER, V. Óleos voláteis. IN: SIMÕES, C. M. O, SCHENKEL, E. P., GOSMANN, G., MELLO, J. C. P. DE, MENTZ, L. A., PETROVICK, P. R. Farmacognosia: da planta a o medicamento. 5.ed. Florianópolis: E ditora da UFRGS/Editora da UFSC, 2004. cap. 18, p. 475.

SIMONETTI, E.; ETHUR, M. E.; CASTRO, L. C.; KAUFFMANN, C.; GIACOMIN, A. C.; LEDUR, A.; AROSSI, K.; PACHECO, L. A.; GOETTERT, M. I.; FALEIRO, D.; FREITAS, E. M. Avaliação da atividade antimicrobiana de extratos de Eugenia anomala e Psidium salutare (Myrtaceae) frente à Escherichia coli e Listeria monocytogenes. Revista Brasileira de Plantas Medicinais, v. 18, n. 1, p. 9-18, 2016. https://dx.doi.org/10.1590/1983-084X/15_005

SOBRAL, M.; PROENÇA. C.; SOUZA, M.; MAZINE, F.; LUCAS, E. Myrtaceae in Lista de Espécies da Flora do Brasil. 2016 [citado em 2016 out. 18]. Disponível em: http://floradobrasil.jbrj.gov.br/jabot/floradobrasil/FB10335

SOTO, C. J.; JOHN, O. P.; GOSLING, S. D.; POTTER, J. Age differences in personality traits from 10 to 65: Big Five domains and facets in a large cross-sectional sample. Journal of Personality and Social Psychology, v. 100, p. 330-348, 2011. https://www.ncbi.nlm.nih.gov/pubmed/21171787. https://doi.org/10.1037/a0021717

SOUZA, S. P.; CARDOSO, M.G.; SOUZA, P.E.; GUIMARÃES, L.G.L.; ANDRADE, J.; MALLET, A.C.T.; NELSON, D. L. Óleo essencial de Baccharis tridentata Vahl: composição química, atividade antioxidante e fungitóxica, e caracterização morfológica das estruturas secretoras por microscopia eletrônica de varredura. Revista Brasileira Plantas Medicinais, v. 13, n. 4, p. 456-466, 2011. https://doi.org/10.1590/S151605722011000400011

SPARAGANO, O. A. E.; GEORGE D. R.; HARRINGTON, D. W. J.; GIANGASPERO, A. Significance and Control of the Poultry Red Mite, Dermanyssus gallinae. Annual Review of Entomology, v. 59, p. 447466, 2014. http://www.annualreviews.org/doi/abs/10.1146/annurev-ento-011613-162101 https://doi.org/10.1146/annurev-ento-011613-162101

STEFANELlO, A. É. M.; CERVI, C. A.; WISNIEWSKI Jr. A.; SIMIONATTO, E. L. Composition and seasonal variation of essential oils of Myrcia obtecta (O. Berg) Kiaersk. Var. obtecta, Myrtaceae. Revista brasileira de farmacognosia, v. 20, n. 1, p. 82-86, 2010. http://dx.doi.org/10.1590/S0102695X2010000100017

TABARI, M. A.; YOUSSEFI, M. R.; BARIMANI, A.; ARAGHI, A. Carvacrol as a potente natural acaricide agains Dermanyssus gallinae. Parasitology Research. v. 114, ed. 10, pp. 3801-3806, 2015. https://link.springer.com/article/10.1007\%2Fs00436-015-4610-0

TAKAO, L. K.; IMATOMI, M.; GUALTIERI, S. C. J. Antioxidant activity and phenolic content of leaf infusions of Myrtaceae species from Cerrado (Brazilian Savanna). Brazilian Journal of Biology, v. 75, n. 4, p. 948-952, 2015. http://dx.doi.org/10.1590/1519-6984.03314

TAPONDJOU, A. L.; ALBER, C.; FONTEM, D. A.; BOUDA, H.; REICHMUTH, C. Bioactivities of cymol and essential oils of Cupressus sempervirens and Eucalyptus salignaagainst Sitophilus zeamais Motschulsky and Tribolium confusum du Val. Journal of Stored Products Research, v. 41, p. 91-102, 2005. https://doi.org/10.1016/j.jspr.2004.01.004

TEPE, B.; DONNEY, E.; UNLU, M.; CANDAN, F.; DAFERERA, D.; UNLU, G. V.; POLISSIOU, M.; SOKMEN, A. A. Antimicrobial and antioxidative activities of the essential oils and methanol extracts of $S$. Cryptanha (Montbret et Aucher ex Benth) S. multicaulis (Vahl). Food Chemistry, v. 84, p. 519-525, 2004. https://www.ncbi.nlm.nih.gov/pubmed/12860311 https://doi.org/10.1016/S0308-8146(03)00267-X

THE PLANT LIST. Myrtaceae [online]. 2013 [citado em 2015 set. 22]. Disponível em: http://www.theplantlist.org/1.1/browse/A/Myrtaceae 
VILLAÇA, C. L. P. B. Prospecção de produtos naturais para o controle de Ornithonyssus bursa (berlese) (Acari: Dermanyssidae). 2012. 95f. Dissertação (Mestrado em Bioprospecção Molecular) - Universidade Regional do Cariri - PPBM/URCA, Crato, CE, 2012.

WEBER, L. D.; PINTO, F. G. S.; SCUR, M. C.; SOUZA, J. G. L.; COSTA, W. F.; LEITE, C. W. Chemical composition antimicrobial and antioxidante activity of essential oil and various plant extratcs from Prumus myrtifolia. African Journal of Agricultural Research, v. 9, p. 846-853, 2014.

http://www.academicjournals.org/journal/AJAR/article-references/AE3B24844788

https://doi.org/10.5897/AJAR2013.8260

XAVIER, M. N.; ALVES, J. M.; CARNEIRO, N. S.; SOUCHIE, E. L.; SILVA, E. A. J.; MARTINS H. G.; AMBRÓSIO, M. A. L. V.; EGEA, M. B.; ALVES, C. C. F.; MIRANDA, M. L. D. Composição Química do Óleo Essencial de Cardiopetalum calophyllum Schltdl (Annonaceae) e suas Atividades Antioxidante, Antibacteriana e Antifúngica. Revista Virtual de Química, v. 20, n. 20, 2016. http://dx.doi.org/10.1590/0103$8478 \mathrm{cr} 20150371$

YOKOMIZO, N. K. S.; NAKAOKA-SAKITA, M. Atividade antimicrobiana e rendimento do óleo essencial de Pimenta pseudocaryophyllus var. pseudocaryophyllus (Gomes) Landrum, Myrtaceae. Revista Brasileira de Plantas Medicinais, v. 16, n. 3, p.513-520, 2014. https://doi.org/10.1590/1983-084X/12_097 